\title{
Compression Speed as a Parameter Changing the Dimensionality of Corrole Nanostructures in Layers at the Air-Water Interface
}

\author{
Thao T. Vu, ${ }^{\text {a }}$ Nadezhda V. Kharitonova, ${ }^{\text {b }}$ Larissa A. Maiorova, ${ }^{\text {b@ }}$ Olga A. Gromova, ${ }^{c}$ \\ Ivan Yu. Torshin, ${ }^{\mathrm{d}}$ and Oskar I. Koifman ${ }^{\mathrm{b}, \mathrm{e}}$ \\ ${ }^{a}$ National University, Hanoi, Vietnam \\ ${ }^{\mathrm{b}}$ Research Institute of Macroheterocyclic Compounds, Ivanovo State University of Chemistry and Technology, 153000 \\ Ivanovo, Russian Federation \\ 'Ivanovo State Medical Academy, 153000 Ivanovo, Russian Federation \\ dInstitute of Modern Information Technologies in Medicine, Federal Research Center "Computer Science and Control” RAS, \\ 119333 Moscow, Russian Federation \\ ${ }^{\mathrm{e}}$ G.A. Krestov Institute of Solution Chemistry, Russian Academy of Sciences, 153045 Ivanovo, Russian Federation \\ @Corresponding author E-mail: Maiorova.Larissa@gmail.com
}

\begin{abstract}
An influence of compression speed of a layer on the structure and properties of stable floating layers of 5,10,15-triphenylcorrol was investigated. Model of face-on monolayers with an increased (by $30 \%$ compared to the quasi-stationary) compression rate has been constructed by method of quantitative analysis of isotherms. It was shown that an increase in the compression speed leads to an increase in the density of both two-dimensional nanoaggregates formed in the layer and the monolayer itself. In addition, there was a significant shift in the boundaries of the existence of floating mono and multilayers in the direction of smaller values of the initial degree of surface coverage.
\end{abstract}

Keywords: Air-water interface, M-nanoaggregates, model of the floating layer, compression speed of the layer, corroles.

\section{Скорость сжатия как параметр, изменяющий размерность наноструктур коррола в слоях на границе раздела воАа-возАух}

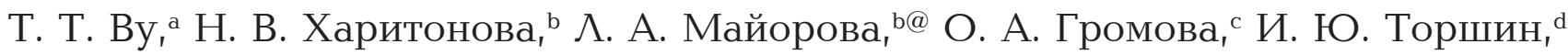 \\ О. И. Койфман
}

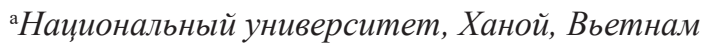

${ }^{\mathrm{b}}$ Институт макрогетероциклических соединений, ФГБОУ ВО «Ивановский государственньй химикотехнологический университет», 153000 Иваново, Российская Федерация

${ }^{ }$ФГБОУ ВО «Ивановская государственная медицинская академия» МЗ РФ, 153000 Иваново, Российская Федерация ${ }^{\mathrm{d}}$ ФИЦ ИУ РАН «Институт современных информационных технологий в медицине», 119333 Москва, Российская Федерация

${ }^{\mathrm{e}}$ Институт химии растворов им. Г.А. Крестова РАН,153045 Иваново, Российская Федерация

${ }^{\circledR}$ E-mail: Maiorova.Larissa@gmail.com

Исследовано влияние скорости сжатия слоя на структуру и свойства стабильных плаваюших слоев 5,10,15-трифенилкоррола. С помощьюю метода количественного анализа изотерм построена модель fасе-оп монослоев, формируемых при скорости сжатия слоя на 30 \% превышающей скорость, обеспечивающую квазистационарный процесс. Показано, что увеличение скорости сжатия приводит к повыцению плотности как формируемых в слое двумерных наноагрегатов, так и самого монослоя. Кроме того, происходит значительный сдвиг грании существования плавающих моно и полислоев в сторону меньших значений исходной степени покрытия поверхности.

Ключевые слова: Граница раздела вода-воздух, М-наноагрегаты, модель монослоя, скорость сжатия слоя, корролы. 


\section{Introduction}

Nowadays, self-organization of macroheterocyclic compounds is an object of intensive research. ${ }^{[1-8]}$ Corroles are tetrapyrrole macrocyclic compounds containing a direct pyrrole-pyrrole bond, ${ }^{[9-15]}$ and having a carbon skeleton similar to vitamin $\mathrm{B}_{12}$. These compounds represent the unique class of porphyrinoids. ${ }^{[16-22]}$ As a trianionic ligand, corrole has the ability to stabilize high oxidation states of the central atoms of metals, such as $\mathrm{Cr}^{\mathrm{V}}, \mathrm{Mn}^{\mathrm{IV}}, \mathrm{Fe}^{\mathrm{IV}}$, $\mathrm{Co}^{\mathrm{IV}}, \mathrm{Cu}^{\mathrm{III}} \cdot{ }^{[23-24]}$ Derivatives of corroles are promising candidates for using them as chemical sensors, ${ }^{[25]}$ catalysts, ${ }^{[26]}$ photosensitizers, ${ }^{[27]}$ and building blocks of supramolecular structures. ${ }^{[28-30]}$ The properties of systems based on this class of compounds are determined by the structure of their ensembles. Therefore the creation of thin-film organic materials, the structural and functional units of which will be two- and three-dimensional nanoparticles of corroles is of great interest.

The Langmuir-Blodgett method makes it possible to solve such problems. ${ }^{[31-35]}$ This method is used to form films of organic compounds with a predetermined structure and thickness in the nanometer range. ${ }^{[36,37]}$ Properties of such systems largely depend on their state in a solution, in floating layers and in films. ${ }^{[38-43]}$ In our previous studies we have demonstrated that the controlled self-organization of organic compounds in $2 D$ and $3 D$ nanostructures at the air-water interface becomes possible if quantitative information about the structure of the floating layer is available. ${ }^{[44,46]}$ The quantitative method for analyzing of compression isotherms of the monolayers using the generalized Volmer equation was developed. ${ }^{[47]}$ It was shown that in the general case the structural elements of the layer are two-dimensional aggregates $5-20 \mathrm{~nm}$ in size ( $M$-nanoaggregates) that can merge into larger nano- and microaggregates. ${ }^{[36,44]}$

It was also shown that corroles at the air-water interface form nanostructured floating mono- and multilayers. ${ }^{[45,46]}$ The effect of the initial surface coverage on the structure of the floating layers of 5,10,15-triphenylcorrol $\left(\mathrm{H}_{3}[(m s-\right.$ $\left.\left.\mathrm{Ph})_{3} \mathrm{Cor}\right]\right)^{[45,46]}$ and effect of temperature of subphase on the layers of (7,13-dimethyl-2,3,8,12,17,18-hexamethylcorrolato)manganese(III) ${ }^{[48]}$ was demonstrated. It was revealed that triphenylcorrole is able to form $J$-aggregates in thin films. ${ }^{[45,49-51]}$ The formation of floating layers was carried out in quasi-stationary conditions (compression speed was $\left.2.3 \mathrm{~cm}^{2} \cdot \mathrm{min}^{-1}\right)$. It is known that the compression speed influences on the process of formation of floating layers of organic compounds. ${ }^{[52-54]}$ However, the effect of the compression speed on the quantitative characteristics of the nanostructured layers (such as the number of molecules in two-dimensional nanoaggregates, density of monolayer, and others) has not yet been studied. The objectives of this work are (1) to obtain the floating nanostructured layers of 5,10,15-triphenylcorrole at a higher than the quasi-stationary compression speed; (2) to determine the main characteristics of M-monolayers and the dependence of the characteristics on the initial surface coverage; (3) to develop a model and to create a passport of floating monolayers; (4) to study the effect of the compression speed on the quantitative characteristics and properties of the nanostructured layers of triphenylcorrole.

\section{Experimental}

5,10,15-Triphenylcorrole was synthesized as described earlier. ${ }^{[46,55,56]}$ The structure of the compound was confirmed by UV-vis, ${ }^{1} \mathrm{H}$ NMR and MALDI-TOF spectra.

The experiment was carried out on the Langmuir trough "NT-MDT" (Zelenograd, Russia). The surface pressure was measured by a Wilhelmy plate with an accuracy of $0.02 \mathrm{mN} / \mathrm{m}$. To obtain the floating layers the solution of $\mathrm{H}_{3}\left[(m s-\mathrm{Ph})_{3} \mathrm{Cor}\right]$ in dichloromethane $\left(C=1.2 \cdot 10^{-4} \mathrm{M}\right)$ was applied onto the surface of bidistilled water with a microliter syringe $(100 \mu 1$, Hamilton, Sweden) at the temperature of $22 \pm 1{ }^{\circ} \mathrm{C}$. The volume of the solution to be applied was determined according to the required initial surface coverage degree $\left(c_{\text {face }}\right)$, i.e. the ratio of the area occupied by the molecules of the substance to the total area of water surface available to the molecules. Fifteen minutes after the application of the solution the layer was compressed at two different speeds of $v=2.3 \mathrm{~cm}^{2} \cdot \mathrm{min}^{-1}$ and $3.2 \mathrm{~cm}^{2} \cdot \mathrm{min}^{-1}$. Floating layers in this work were formed at $c_{\text {face }}$ values varied within $5.4-50.5 \%$.

The structure of the layers at air-water interface was analyzed using quantitative analysis of compression isotherms of a nanostructured $M$-monolayer, based on the concept of a layer as a real two-dimensional gas with structural elements representing twodimensional nanoaggregates. ${ }^{[31,47,57,59]}$ The stable state of the layer is described by equation

$$
\pi \cdot\left(A-A_{m o l}\right)=k T / n
$$

where $\pi$ is the surface pressure, $A$ is the area per molecule in the layer, $A_{\text {mol }}$ is the area per molecule in the nanoaggregate, $k$ is the Boltzmann constant, $T$ is the absolute temperature and $n$ is the aggregation number. When plotted in $\pi A-\pi$ axes, a compression isotherm of the floating layer has both linear (corresponding to the singlephase states of the layer) and nonlinear regions. The $A_{m o l}$ and $n$ are the main characteristics of a floating monolayer; these values may be determined by approximating the $\pi A-\pi$ plot using a linear function (the least squares method was used and the $\pi A$ error did not exceed $3 \%$ ). The area per molecule in the nanoaggregate may also be determined from the $\pi A-\pi$ graph as the slope of a straight segment which approximates the linear portion of the graph corresponding to the stable state of the layer. The number of molecules in the aggregate may be calculated as $n=k T / \beta$, where $\beta$ is the ordinate of intersection of the straight line and the ordinate axis. According to the model used, the $\mathrm{M}$ unit has the circular shape with the area $S_{\text {aggr }}=n A_{\text {mol }}$ and diameter $D_{\text {aggr }}=2\left(S_{\text {aggr }} / \pi\right)^{1 / 2}$. The layer compressibility at a stable state was calculated as $B=\left(1-A_{f} / A_{0}\right)$ ) $\left(\pi_{f}-\pi_{i}\right)$, where $\pi_{i}$, and $\pi_{f}$ are pressures at the initial and final points of a stable layer state and $A_{i}$ and $A_{f}$ are the areas at the beginning and at the end of the linear section of the $\pi-A$ isotherm, respectively. The distance between aggregate boundaries may be calculated as $d_{i}=2(n / \pi)^{1 / 2}\left(A_{i}^{1 / 2}-A_{m o l}^{1 / 2}\right)$. The average distance between molecules in the aggregate where the planes of $\mathrm{H}_{3}\left[(m s-\mathrm{Ph})_{3} \mathrm{Cor}\right]$ molecules are arranged along the water surface (a $M_{\text {face }}$-aggregate) is $r=2 / \pi^{1 / 2}\left(A_{m o l}^{1 / 2}-A_{p r o j}{ }^{1 / 2}\right)$. The water content per molecule in $M$-aggregates may be determined as $w_{i n-M}=A_{m o l}-A_{p r o j}$, where $A_{p r o j}$ is the area of the molecule's projection onto the water surface, and the same between aggregates (at the initial point of the stable state) may be determined as $w_{\text {inter }-M}=A_{i}-A_{\text {mol }}$.

For aggregates where the molecules are tilted to the surface of water, one can determine the minimum inclination angle of molecules in stacks (in the case of so-called "dry" aggregates): $\psi_{\text {min }}=\arcsin \left(A_{\text {pack-edge }} / A_{\text {moo }}\right)$, where $A_{\text {pack-edge }}$ is the area per molecule in closest packing. It is also possible to calculate such values as: the current surface coverage degree at the start and end points of the stable state $c_{i}=A_{p r o j} / A_{i}$ and $c_{f}=A_{p r o j} / A_{f}$; the surface coverage degree extent of the stable state $\left(\Delta c_{j}\right)$; the degree 
of coverage of the water surface by aggregates at the onset point of the stable state $c_{i-a g r v}=A_{m o l} / A_{i}$; the pressure extent of the stable state, $\Delta \pi=\pi_{i}-\pi_{f}$. The density of the aggregate is calculated with the equation $\rho_{\text {aggr }}=A_{\text {proj }} / A_{\text {mol }}$.

The area $(A)$ per molecule in the layer was determined with $2 \%$ error. The maximum error values for other characteristics are as follows: $3 \%$ for $A_{m o l}$ and $\Delta \pi ; 5 \%$ for $c_{\text {face }}, r$ and $\psi ; 6 \%$ for $S_{a g g r}$; $7 \%$ for $D_{\text {aggr }}$ and $w_{\text {inter-M-I }}-7 \% ; 10 \%$ for $B, c_{\text {ifface }}, c_{\text {fface }}, c_{i \text {-edge }}, c_{\text {f-edge' }}$ $c_{i-a g g r}, n, \rho_{a g g r}, w_{i n-M,}$ and $d_{i}-10 \%$.

To analyze the compression isotherms, molecular models and corresponding face-on and edge-on closest packings were built using the HyperChem 8.0.8 software package ( $\mathrm{PM}_{3}$ calculation method). The geometric parameters of the molecule are as follows: projection areas $A_{\text {proj(face) }}=1.6 \mathrm{~nm}^{2}, A_{\text {proj(edge) }}=1 \mathrm{~nm}^{2}$; areas of circumscribed rectangles $A_{\text {rec(face) }}=3.2 \mathrm{~nm}^{2}$ and $A_{\text {rec(edge) }}=1.4 \mathrm{~nm}^{2}$. The areas per molecule in the closest-packed monolayer are $A_{\text {packface) }}=1.9 \mathrm{~nm}^{2}$ and $A_{\text {pack(edge) }}=1.2 \mathrm{~nm}^{2}$.

\section{Results and Discussion}

It is shown that compression speed of the floating layers of triphenylcorrole, $v=2.3 \mathrm{~cm}^{2} \cdot \mathrm{min}^{-1}$, is quasi-stationary. Characteristics and formation conditions of a stable monolayer do not depend on compression speed (at $v \leq 2.3 \mathrm{~cm}^{2} \cdot \mathrm{min}^{-1}$ ) and on the number of compression cycles. ${ }^{\text {[59] }}$ To study the effect of compression speed on structure of M-layers of $\mathrm{H}_{3}\left[(m s-\mathrm{Ph})_{3} \mathrm{Cor}\right]$, the compression isotherms of the layers formed at higher compression speed, than quasi-stationary $\left(v=3.2 \mathrm{~cm}^{2} \cdot \mathrm{min}^{-1}\right)$ were recorded. Characteristics of $\mathrm{H}_{3}\left[(m s-\mathrm{Ph})_{3} \mathrm{Cor}\right]$ floating layers, obtained at different initial surface coverage degrees are presented in Table 1. In this range of initial surface coverage stable floating layers of different types are formed: monolayers, bilayers and tetralayers. The compression isotherms

Table 1. Characteristics of $\mathrm{H}_{3}\left[(\mathrm{~ms}-\mathrm{Ph})_{3} \mathrm{Cor}\right]$ floating layers, obtained at different initial surface coverage degrees (compression speed $v=3.2 \mathrm{~cm}^{2} \cdot \mathrm{min}^{-1}$ ).

\begin{tabular}{|c|c|c|c|c|c|c|c|c|c|c|c|c|c|}
\hline $\begin{array}{c}c_{\text {face }} \\
\left(c_{\text {edge }}\right) \\
(\%)\end{array}$ & $\begin{array}{c}\text { Nano-aggregate } \\
\text { type }\end{array}$ & $\begin{array}{c}c_{i \text {-face }}-c_{\text {f-face }} \\
\left(\Delta c_{j \text {-face }}\right) \\
(\%)\end{array}$ & $\begin{array}{l}c_{\text {i-aggr }} \\
(\%)\end{array}$ & $\begin{array}{c}\pi_{i}-\pi_{f} \\
(\mathrm{mN} / \mathrm{m})\end{array}$ & $\begin{array}{l}A_{m o l} \\
\left(\mathrm{~nm}^{2}\right)\end{array}$ & $n$ & $\begin{array}{l}D_{a g g r} \\
(\mathrm{~nm})\end{array}$ & $\begin{array}{l}\psi_{\min } \\
\left({ }^{\circ}\right)\end{array}$ & $\begin{array}{c}r \\
(\mathrm{~nm})\end{array}$ & $\begin{array}{c}w_{i n-M} / A_{m o l} \\
(\%) \\
\left(\rho_{a g g r}\right)\end{array}$ & $\begin{array}{l}w_{\text {inter-M-i }} \\
\left(\mathrm{nm}^{2}\right)\end{array}$ & $\begin{array}{c}d_{i} \\
(\mathrm{~nm})\end{array}$ & $\begin{array}{c}B \\
(\mathrm{~m} / \mathrm{N})\end{array}$ \\
\hline \multicolumn{14}{|c|}{$\mathrm{H}_{3}\left[(m s-\mathrm{Ph})_{3} \mathrm{Cor}\right] C=1.2 \cdot 10^{-4} \mathrm{M}$} \\
\hline $5.4(2.4)$ & \multirow{3}{*}{$\begin{array}{l}\text { Mono } \\
M_{\text {face }}\end{array}$} & $35-36(1)$ & 80 & $0.2-0.3$ & 3.7 & 55 & 16 & 0 & 0.7 & $57(0.43)$ & 0.9 & 1.9 & 360 \\
\hline $7.7(3.4)$ & & $46-52(6)$ & 81 & $0.2-0.3$ & 2.8 & 62 & 15 & 0 & 0.5 & $43(0.57)$ & 0.7 & 1.7 & 690 \\
\hline $8.7(3.8)$ & & $50-57(7)$ & 82 & $0.2-0.4$ & 2.5 & 67 & 15 & 0 & 0.4 & $36(0.64)$ & 0.7 & 1.8 & 580 \\
\hline $14.2(6.2)$ & \multirow{2}{*}{$\begin{array}{c}\text { Mono } \\
M_{\text {edge }} \\
\end{array}$} & $62-80(18)$ & 64 & $0.2-0.6$ & 1.6 & 20 & 7 & 48 & - & $26^{*}(0.74)$ & 1.0 & 1.7 & 580 \\
\hline $17.5(7.6)$ & & $76-97(21)$ & 67 & $0.2-0.6$ & 1.4 & 27 & 7 & 59 & - & $14^{*}(0.86)$ & 0.7 & 1.5 & 540 \\
\hline $21.8(9.5)$ & $\begin{array}{c}\text { Bi-layer } \\
M_{b i}\end{array}$ & $107-139(32)$ & 64 & $0.2-0.6$ & 1 & 34 & 5 & - & - & - & 0.5 & 1.6 & 560 \\
\hline $50.5(22.1)$ & $\begin{array}{c}\text { Tetra-layer } \\
M_{\text {tetra }}\end{array}$ & $160-291(131)$ & 46 & $0.2-1.4$ & 0.5 & 41 & 2 & - & - & - & 0.5 & 2.3 & 380 \\
\hline
\end{tabular}

$c_{\text {face }} / c_{\text {edge }}$ face-on and edge-on are initial surface coverage degrees; $c_{i \text { (face,edge) }}$ and $c_{\text {ffface,edge) }}$ are surface coverage degrees at the initial and final points of the stable state respectively; $\Delta c_{j \text {-face }}$ is span of surface coverage degree, region where the state exists; $c_{i \text {-aggr }}$ is surface coverage degree by $M$-aggregates at the initial point of the stable state; $\pi_{i}-\pi_{f}$ is the pressure region where the stable state exists, and the span of the region; $A_{m o l}$ is surface area per molecule in a nanoaggregate; n aggregation number (the number of molecules in an aggregate); $D_{a g g r}$ and $S_{a g g r}$ are diameter and surface area of a nanoaggregate; $\psi_{\text {min }}$ is the lowest tilt angle of molecules in stacks ("dry" aggregates); $r$ is the average distance between molecules in the aggregate; $w_{i n-M} / A_{m o l}$ and $w_{\text {inter-M-i }}$ are water content in $M$-aggregates and between them (per molecule) at the initial point of the stable state; $\rho_{a g g r}$ is density of the aggregate; $d_{i}$ is the distance between nanoaggregates at initial points of the stable state; $B$ is compressibility of the layer.

*the amount of water in the aggregates was calculated for vertical arrangement of the molecules in the stacks.
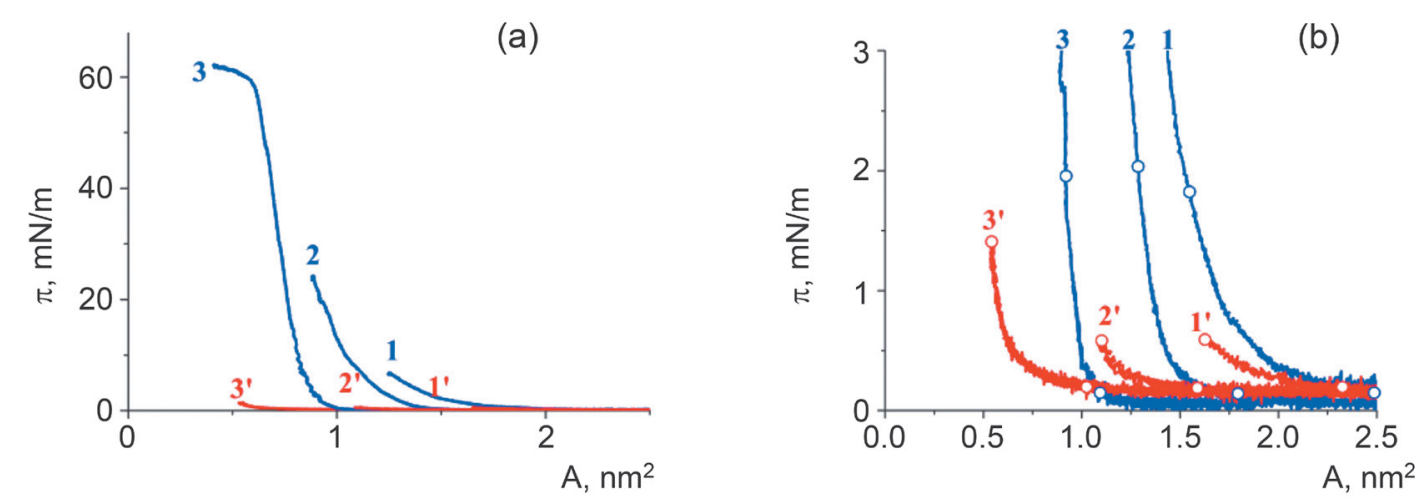

Figure 1. $\pi$ - $A$ - Compression isotherms of floating layers of $\mathrm{H}_{3}(m s-\mathrm{Ph})_{3}$ Cor (a) and low-pressure region of the same isotherms (b).

The isotherms were recorded for $C=1.2 \cdot 10^{-4} \mathrm{M}\left(\mathrm{CH}_{2} \mathrm{Cl}_{2}\right)$ at two different compression speeds: $v=2.3 \mathrm{~cm}^{2} \cdot \mathrm{min}^{-1} ; c_{\text {face }}=17.5 \%$ (1), $27.2 \%$ (2), $61.9 \%$ (3) - blue lines and $v=3.2 \mathrm{~cm}^{2} \cdot \mathrm{min}^{-1} ; \mathrm{c}_{\text {face }}=17.5 \%\left(1^{\prime}\right), 21.8 \%\left(2^{\prime}\right), 50.5 \%\left(3^{\prime}\right)$ - red lines. 

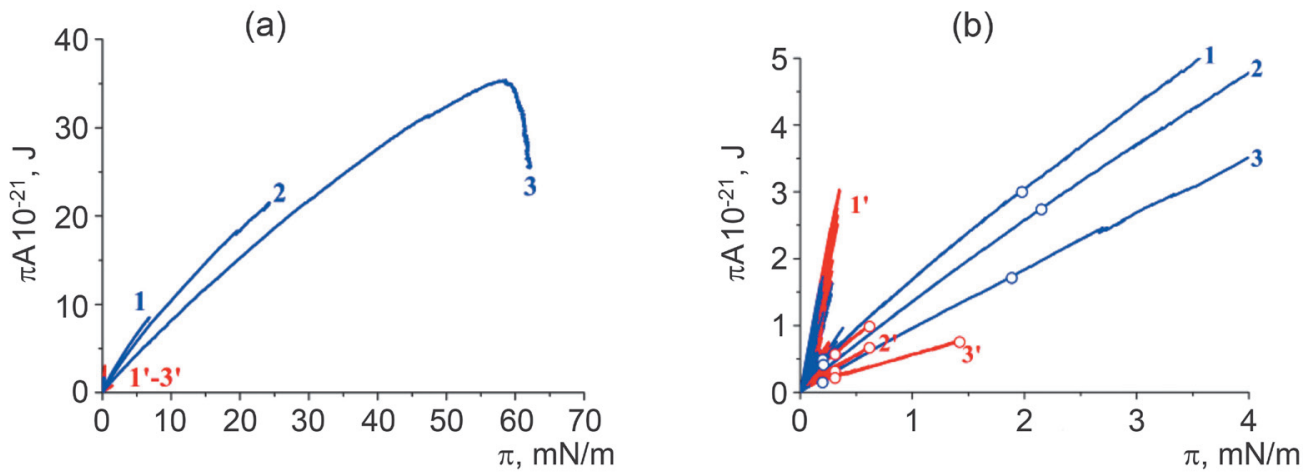

Figure 2. $\pi A-\pi$-Compression isotherms of floating layers of $\mathrm{H}_{3}(m s-\mathrm{Ph})_{3} \mathrm{Cor}$ (a) and low-pressure region of the same isotherms (b). The isotherms were recorded for $C=1.2 \cdot 10^{-4} \mathrm{M}\left(\mathrm{CH}_{2} \mathrm{Cl}_{2}\right)$ at two different compression speeds: $v=2.3 \mathrm{~cm}^{2} \cdot \mathrm{min}^{-1} ; c_{\text {face }}=17.5 \%(1), 27.2 \%(2)$, $61.9 \%$ (3) - blue lines and $v=3.2 \mathrm{~cm}^{2} \cdot \mathrm{min}^{-1} ; \mathrm{c}_{\text {face }}=17.5 \%\left(1^{\prime}\right), 21.8 \%\left(2^{\prime}\right), 50.5 \%\left(3^{\prime}\right)$ - red lines.

of the layers obtained at different compression speed are presented in Figures 1, 2.

At compression speed $v=3.2 \mathrm{~cm}^{2} \cdot \mathrm{min}^{-1}$ and at low initial surface coverage ( $c_{\text {face }} \leq 9 \%$ ), face-on monolayers are formed (where molecules in nanoaggregates are parallel to the water surface). Such monolayers are characterized by large values of numbers of molecules in aggregates $(n=55-67)$ and big size of aggregates (an average of $15-16 \mathrm{~nm}$ in diameter). They are also characterized by large values of water content per molecule in $M$-aggregates (from $57 \%$ to $36 \%$ ) and large water content per molecule between $M$-aggregates $(0.9-$ $0.7 \mathrm{~nm}^{2}$ per molecule).

In a narrow range of initial surface coverage degree $\left(14 \leq c_{\text {face }} \leq 18 \%\right)$ and at pressures up to $0.4 \mathrm{mN} / \mathrm{m}$, stable edge-on monolayers are formed (where molecules in nanoaggregates are tilted to the water surface). The minimum tilted angle of the molecules in stacks is $48-59^{\circ}$, the number of molecules in the $M_{\text {edge }}$ aggregates is 17-27 and water content per molecule between M-aggregates is $0.7-1.0 \mathrm{~nm}^{2}$.

The surface coverage degree by face-on $M$-aggregates $\left(c_{a g g}\right)$ at the initial point of the stable state does not depend on $c_{\text {face }}\left(c_{i-a g g r}=81 \%\right)$. The average value of $c_{i-a g g r}$ for edgeon monolayers is $66 \%$. At surface coverage $c_{\text {face }}=21.8 \%$, a bilayer is formed. At $c_{\text {face }}=50.5 \%$ a tetralayer is formed.

Analyzing dependencies of characteristics of face-on monolayer on the initial surface coverage degree (Table 1, Figure 3) results in the following equations:

$$
\begin{aligned}
& A_{\text {mol }}=5.69-0.37 \cdot c_{\text {face }} \\
& n=35.95+3.49 \cdot c_{\text {face }} \\
& D_{\text {aggr }}=17.7-0.32 \cdot c_{\text {face }} \\
& w_{\text {in-M }} / A_{\text {mol }}=91.6-6.36 \cdot c_{\text {face }} \\
& w_{\text {inter-M- }}=1.22-0.06 \cdot c_{\text {face }} \\
& \left(c_{\text {i-aggr }}\right)^{\text {const }}=80 \%
\end{aligned}
$$

The constants characterizing floating layers were determined from the equations (2)-(7): $\left(A_{m o l}\right)^{m i n}=1.9 \mathrm{~nm}^{2}$, $(n)^{\max }=72, \quad\left(D_{\text {aggr }}\right)^{\min }=14.4 \mathrm{~nm}, \quad\left(w_{\text {in }-M^{-1} / A_{\text {mol }}}\right)^{\min }=26 \%$, $\left(w_{\text {inter-M-i }-i}\right)^{\min }=0.6 \mathrm{~nm}^{2}, \quad\left(c_{i-a g g r}\right)^{\max }=58 \%$. Note, that constants characterizing monolayer at a lower compression speed $\left(v=2.3 \mathrm{~cm}^{2} \cdot \mathrm{min}^{-1}\right)$ are: $(n)^{\max }=45,\left(D_{\text {agg }}\right)^{\text {const }}=11 \mathrm{~nm}$, $\left(c_{\text {i-aggr }}\right)^{\text {const }=75} \%{ }^{[45]}$ Thus, as compression speed of the layer increases, the maximum number of molecules in the aggregates, the diameter of the aggregate and the density of the monolayer increase. The dependencies of surface area per molecule in a $M$-aggregate, the number of molecules in an aggregate, diameter of a $M$-nanoaggregates, water content per molecule in a nanoaggregates, water content between a nanoaggregates (per molecule) and surface coverage of a $M$-aggregates on the initial surface coverage are shown in Figure 3. The boundaries of the regions of monolayers with different types of nanoaggregates are determined: $c_{\text {bord-face-edge }}=10.2 \%, c_{\text {bord-edge-bi }}=19.7 \%$, $c_{\text {bord-bi-tetra }}=36.2 \%$.

It is shown that an increase in the compression rate leads to a decrease in the area per molecule in the aggregate (Figures 3a, 4) and a shift of the boundaries between layers of different types towards a lower degree of surface coverage $\left(\Delta c_{\text {face }}=1.9 \%\right.$ for face-on monolayers, $\Delta c_{\text {face }}=15.1 \%$ for edge-on monolayers and $\Delta c_{\text {face }}=43.2 \%$ for bilayer). At a high compression speed less stable layers with more dense nanoaggregates are formed. At low surface coverage $\left(c_{\text {face }}\right.$ up to $18 \%$ ), the number of molecules in aggregates is larger than in the case of quasi-stationary compression of the layer. At $c_{\text {face }}$ of $20 \%$, the opposite trend is observed (Figure 3b).

Schematic views of floating monolayers and $3 D$ nanoaggregates of triphenylcorrole obtained at different compression speed are shown in Figure 4.

\section{Conclusion}

In this work it was shown that an increase in the compression speed by $30 \%$ leads not only to a significant shift of the boundaries between floating layers of different types, but also to a decrease of the stability of the monolayer. The characteristics of the layers are also changed. The corrole-corrole interactions (face-to-face) start to prevail over corrole-water interactions at a lower value of initial surface coverage ( $c_{\text {face }}=14.2 \%$ instead of $17.5 \%$ ). The edgeto-edge interactions between stacks in floating layers begin to dominate over the corrole-water interactions at almost two times lower value of initial surface coverage. Bilayers at high compression rate are formed at $c_{\text {face }}=20 \%$. Tetralayers are formed at $c_{\text {face }}=38 \%$. Therefore, compression speed, as well as the initial surface coverage and temperature, 
(a)

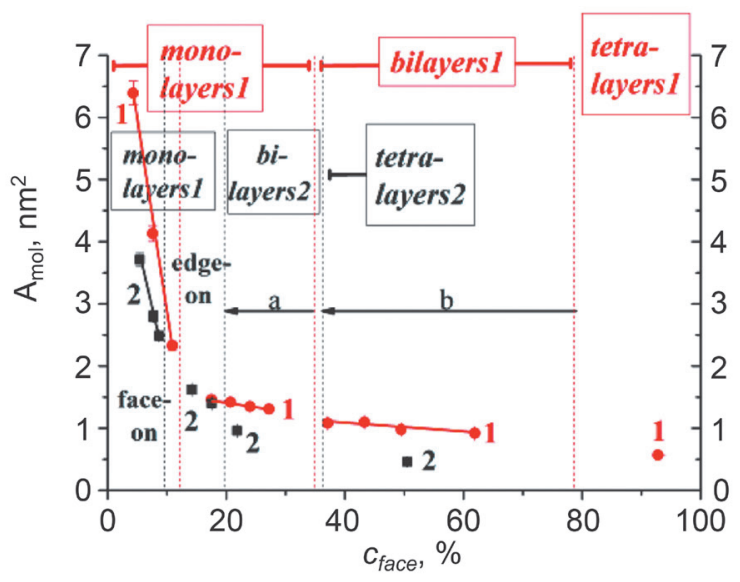

(c)

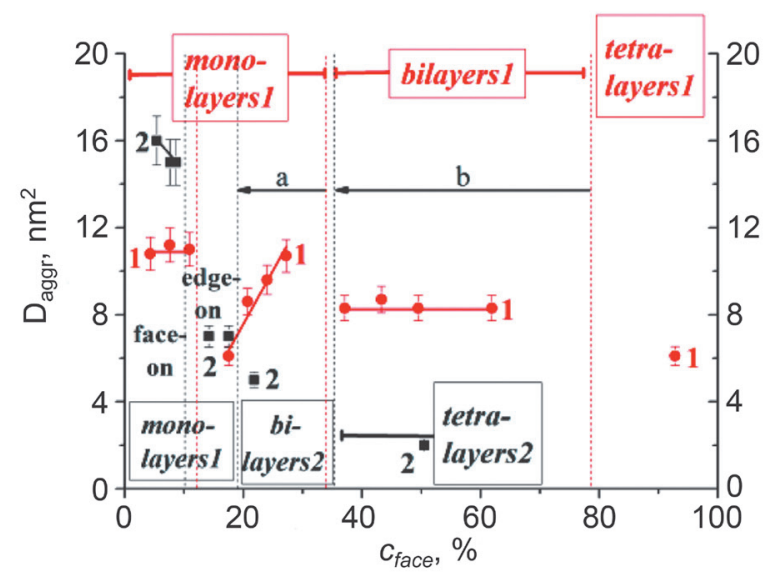

(e)

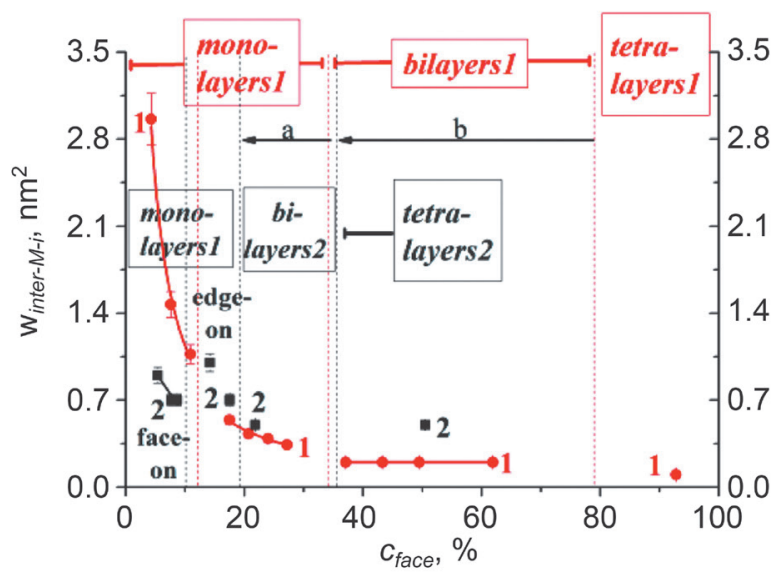

(b)

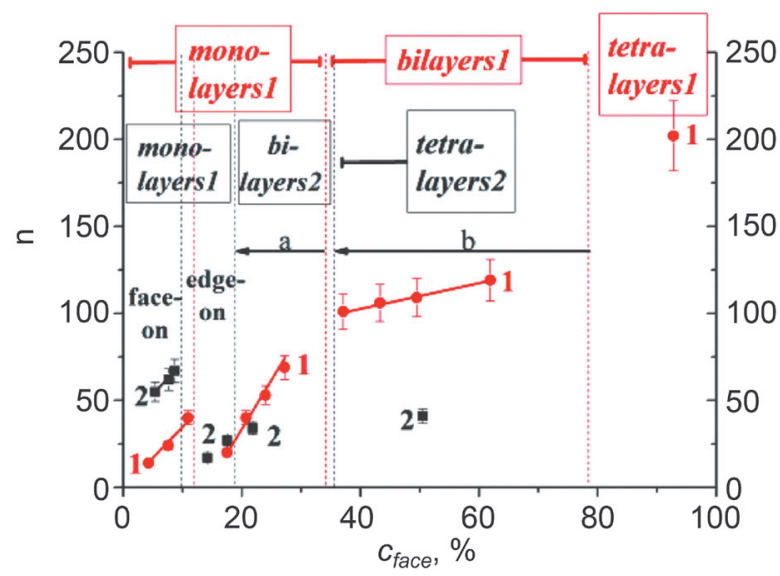

(d)

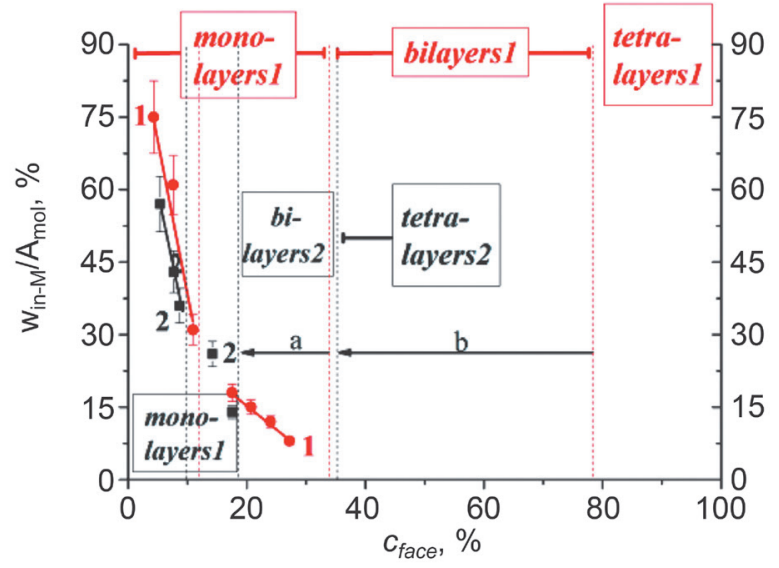

(f)

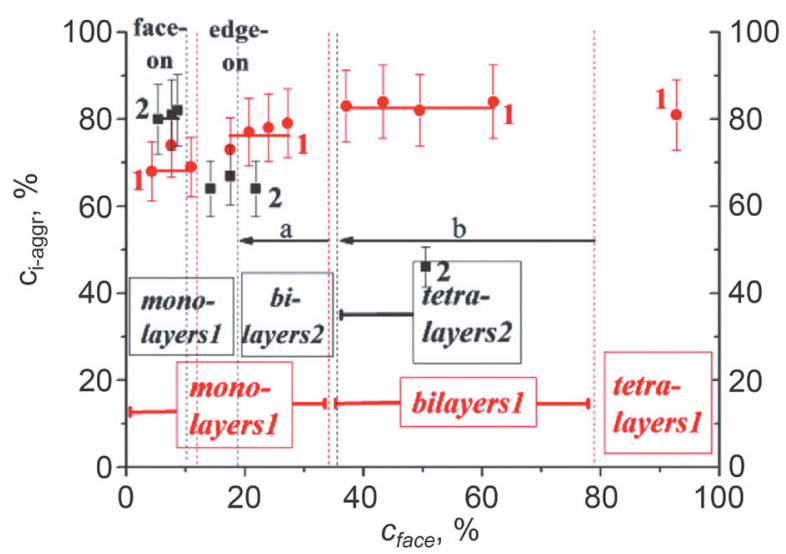

Figure 3. The dependencies on the initial surface coverage degree for: the area per molecule in $M$-aggregate $\left(A_{\text {mol }}\right)$ (a), the aggregation number $(n, \mathrm{~b})$, the diameter of $M$-nanoaggregates $\left(D_{a g g}\right)(\mathrm{c})$, the content of water in nanoaggregates $\left(w_{\text {in }} / A_{\text {mol }}\right)(\mathrm{d})$, content of water between nanoaggregates $\left(w_{\text {inter-Mi-i }}\right.$ per molecule) $(\mathrm{e})$ and the surface coverage degree by $M$-aggregates $\left(c_{i-a g g r}\right)(\mathrm{f})$. For graphs (e) and (f) the values are determined at the initial and final points of the stable state, respectively. The dependencies are obtained for two different compression rates of the floating layer $v=2.3 \mathrm{~cm}^{2} \cdot \mathrm{min}^{-1}$ (1, red lines and points) and $v=3.2 \mathrm{~cm}^{2} \cdot \mathrm{min}^{-1}$ (2, black lines and dots). Vertical dashed lines show the boundaries between layers of different types. 
(a')

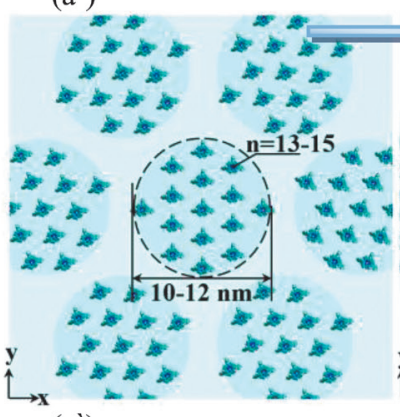

(c') $\left(a^{\prime \prime}\right)$

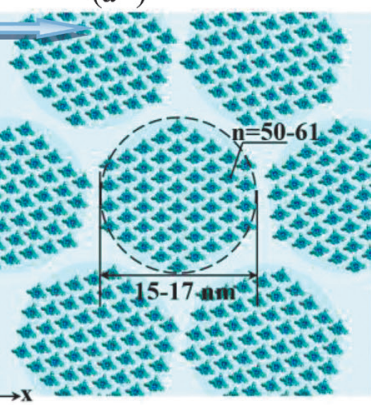

$\left(c^{\prime \prime}\right)$ (b')

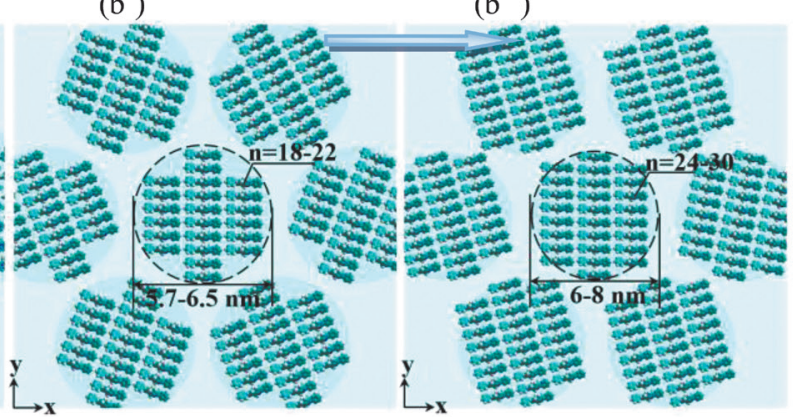

(d')

(d")
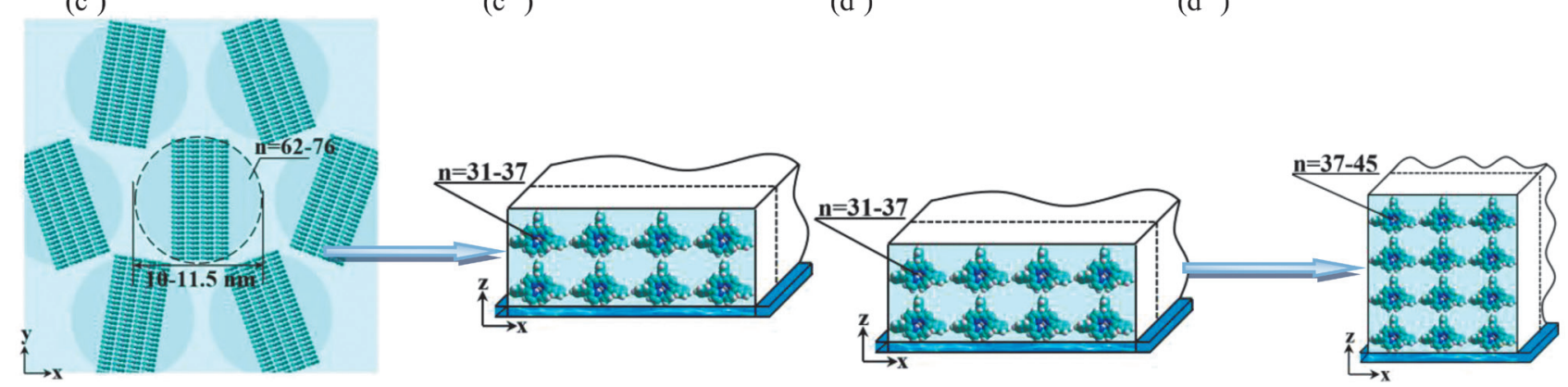

Figure 4. Schematic views of fragments of floating monolayers and $3 D$ nanoaggregates of triphenylcorrole at different compression speed of the layer. (a) Monolayers with $M_{\text {face }}$ nanoaggregates: $v=2.3 \mathrm{~cm}^{2} \cdot \mathrm{min}^{-1}\left(\mathrm{a}^{\prime}, c_{\text {face }}=5.4 \%\right.$ ) and $v=3.2 \mathrm{~cm}^{2} \cdot \mathrm{min}^{-1}\left(\mathrm{a}^{\prime \prime}, c_{\text {face }}=4.3 \%\right)$. (b) Monolayers with $M_{\text {edge }}$ nanoaggregates: (b`and $\mathrm{b}^{\prime \prime}$, respectively, $c_{\text {face }}=17.5 \%$ ). (c) Change in dimension of nanoaggregates $(2 D-3 D)$ : monolayers-bilayers ( $c^{\prime}, c_{\text {face }}=61.9 \%$ and $\mathrm{c}^{\prime \prime}, c_{\text {face }}=50.5 \%$ ). (d) The change in the structure of $3 D$ aggregates: bilayers-tetralayers (d' and $\mathrm{d}^{\prime}, c_{\text {face }}=50.5 \%$ ).

is a parameter of the directional change of the structure and properties of organic compounds in the layers at air-water interface.

Acknowledgements. This work is partially supported by the Russian Science Foundation (Project 14-23-00204-p, compression isotherms) and the government task of the Ministry of Education and Science of the Russian Federation (4.1929.2018/4.6, model of floating layers).

\section{References}

1. Islyaikin M.K., Trukhina O.N., Romanenko Y.V., Danilova E.A., Khelevina O.G. Macroheterocycles 2008, 1, 30-39.

2. Berezin B.D. Coordination Compounds of Porphyrins and Phthalocyanines. Moscow: Nauka, 1978. 280 p. (in Russ.) [Березин Б.Д. Координационные соединения порфиринов и фтталоиианинов. Москва: Наука, 1978. 280 с.].

3. Satake A., Kobuke Y. Tetrahedron 2005, 61, 13-41.

4. Stuzhin P.A., Ercolani C. Porphyrazines with Annulated Heterocycles. In: The Porphyrin Handbook, Vol.15 (Kadish K.M., Smith K.M., Guilard R., Eds.), Amsterdam, Academic Press, 2003. p. 263-364.

5. Valkova L.A., Borovkov N.Yu., Pisani M., Rustichelli F. Thin Solid Films 2001, 401, 267-272.

6. Guldi D.M., Gouloumis A., Vazquez P., Torres T., Georgakilas V., Prato M. J. Am. Chem. Soc. 2005, 127, 5811-5813.

7. Maiorova L.A., Kobayashi N., Zyablov S.V., Bykov V.A., Nesterov S.I., Kozlov A.V., Devillers Ch.H., Zavyalov A.V., Alexandriysky V.V., Orena M., Koifman O.I. Langmuir 2018, 34, 9322-9329.

8. Konev D.V., Devillers Ch.H., Lizgina K.V., Zyubina T.S.,
Zyubin A.S., Maiorova-Valkova L.A., Vorotyntsev M.A. Electrochimica Acta 2014, 122, 3-10.

9. Snow A.W. Phthalocyanines: Properties and Materials. In: The Porphyrin Handbook, Vol. 17 (Kadish K.M., Smith K.M., Guillard R., Eds.) USA, Elsevier Science, 2003. p. 129-176.

10. Paolesse R. Heteroporphyrins, Expanded Porphyrins and Related Macrocycles. In: The Porphyrin Handbook, Vol. 2 (Kadish K.M., Smith K.M., Guilard R., Eds.) New York, Academic Press, 2000. p. 201-232.

11. Paolesse R. Topics in Heterocyc. Chem. 2014, 33, 1-34.

12. Expanded, Contracted and Isomeric Porphyrins (Sessler J.L., Weghorn S.J., Eds.), Tetrahedron Org. Chem. Series, Vol. 15 1997, p. 1-520.

13. Erben Ch., Will S., Kadish K.M. Metallocorroles: Molecular Structure, Spectroscopy and Electronic States. In: The Porphyrin Handbook, Vol. 2 (Kadish K.M., Smith K.M., Guilard R., Eds.) New York, Academic Press, 2000. p. 233-300.

14. Aviv I., Gross Z. Chem. Commun. 2007, 20, 1987-1999.

15. Paolesse R. Syn. Lett. 2008, 15, 2215-2230.

16. Aviv-Harel I., Gross Z. Chem. Eur. J. 2009, 15, 8382-8394.

17. Aviv-Harel I., Gross Z. Coord. Chem. Rev. 2011, 255, 717-736.

18. Karimov D.R. Synthesis, Spectral Characteristics and Reactivity of Corroles with Different Types of Functional Substitution. PhD Diss., Ivanovo, 2011. 159 p. (in Russ.).

19. Palmer J.H. Struct. Bonding 2012, 142, 49-90.

20. Liu H.-Y., Mahmood M. HR, Qiu Sh.-X., Chang Ch. K. Coord. Chem. Rev. 2013, 257, 1306-1333.

21. Barata J.F.B., Santos C.I.M., Grac M., Neves P.M.S., Faustino M.A.F., Cavaleiro J.A.S. Topics in Heterocyclic Chem. 2013, $33,79-141$.

22. Thomas K.E., Alemayehu A.B., Conradie J., Beavers CH.M., Ghosh A. Acc. Chem. Res. 2012, 45, 1203-1214.

23. Meier-Callahan A.E., Gray H.B., Gross Z. Inorg. Chem. 2000, 39, 3605-3607. 
24. Gross Z., Golubkov G., Simkhovich L. Angew. Chem., Int. Ed. 2000, 39, 4045-4047.

25. Paolesse R., Natale C.D., Macognano A., Sagone F., Scarselli M.A., Chiaradia P., Troitsky V.I., Berzina T.S., D’Amico A. Langmuir 1999, 15, 1268-1273.

26. Gross Z., Simkhovich L., Galili N. Chem. Commun. 1999, 599-600.

27. Aviezer D., Cotton S., David M., Segev A., Khaselev N., Galili N., Gross Z., Yayon A. Cancer Res. 2000, 60, 2973-2980.

28. Paolesse R., Pandey R.K., Forsyth T.P., Jaquinod L., Gerzevske K.R., Nurco D.J., Senge M.O., Licoccia S., Boshi T., Smith K.M. J. Am. Chem. Soc. 1996, 118, 3869-3882.

29. Guilard R., Barbe J.M., Stern C., Kadish K.M. Multporphyrins, Multiphthalocyanines and Arrays. In: The Porphyrin Handbook, Vol. 18 (Kadish K.M., Smith K.M., Guilard R., Eds.) Amsterdam, Academic Press, 2003. p. 303-349.

30. Mack J., Kobayashi N., Shen Z. The Properties of Porphyrinoids. In: The Porphyrin Handbook, Vol. 2 (Kadish K.M., Smith K.M., Guilard R., Eds.) Singapore, World Scientific, 2013. p. 281-371.

31. Valkova L., Zyablov S., Erokhin V., Koifman O. J. Porphyrins Phthalocyanines 2010, 14, 513-522.

32. Valkova L.A., Valli L., Casilli S., Giancane G., Borovkov N.Yu., Sibrina G.V., Glibin A.S., Koifman O.I., Pisani M., Rustichelli F. Langmuir 2008, 24, 4857-4864.

33. Mishuck E., Eirich F. In: Monomolecular Layers (Sobotka H., Ed.), Washington, DC: American Association for the Advancement of Science, 1954. p. 25.

34. Valkova L.A., Shabyshev L.S., Feigin L.A., Akopova O.B. Molecular Materials 1996, 6, 291-298.

35. Valkova L.A., Erokhin V.V., Glibin A.S., Koifman O.I. J. Porphyrins Phthalocyanines 2011, 15, 1044-1051.

36. Maiorova L.A. Controlled Self-assembling of Azaporphyrins in 2D- and 3D-Nanostructures in Langmuir Layers and Langmuir-Blodgett Films. Extended Abstract of Doctor of Science (Phys.-Math.) Dissertation, Ivanovo, Russia 2012, $32 \mathrm{p}$.

37. Valkova L.A., Shabyshev L.S., Borovkov N.Yu., Feigin L.A., Rustichelli F. J. Inclusion Phenom. Macrocyclic Chem. 1999, 35, 243-249.

38. Valkova L.A., Betrencourt C., Hochapfel A., Myagkov I.V., Feigin L.A. Mol. Cryst. Liq. Cryst. 1996, 287, 269-273.

39. Valkova L.A., Glibin A.S., Koifman O.I. Macroheterocycles 2011, 4, 222-226.
40. Topchieva I.N., Osipova S.V., Banatskaya M.I., Valkova L.A Doklady Akademii Nauk SSSR 1989, 308(4), 910-913.

41. Myagkov I.V., Studnev Yu.N. Kolloidn. Zh. 1985, 47, 815-821 (in Russ.).

42. Akopova O.B., Bronnikova A.A., Kruvchinskii A., Kotovich L.N., Shabyshev L.S., Valkova L.A. J. Struct. Chem. 1998, 39, 376-383.

43. Pisani M., Maiorova L.A., Francescangeli O., Fokin D.S., Nikitin K.S., Burmistrov V.A., Kuvshinova S.A., Mengucci P., Koifman O.I. Mol. Cryst. Liq. Cryst. 2017, 649, 2-10.

44. Karlyuk M.V., Krygin Y.Y., Maiorova L.A., Ageeva T.A., Koifman O.I. Russ. Chem. Bull. 2013, 62, 471-479.

45. Vu T.T., Maiorova L.A., Berezin D.B., Koifman O.I. Macroheterocycles 2016, 9, 73-79.

46. Maiorova L.A., Vu T.T., Gromova O.A., Nikitin K.S., Koifman O.I. BioNanoScience 2018, 8(1), 81-89.

47. Valkova L.A., Glibin A.S., Valli L. Colloid J. 2008, 70(1), 6-11.

48. Paolesse R., Natale C.D., Macagnano A., Sagone F., Scarselli M. A., Chiaradia P. Langmuir 1999, 15, 1268-1274.

49. Niu T., Zhang J.L., Chen W. RSC Smart Materials: Supramolecular Materials for Opto-Electronics (Koch N., Ed.), Vol 12. GBR: Royal Society of Chemistry: Cambridge 2014. p. 98.

50. Gao Y., Zhang Y., Ren J., Li D., Gao T., Zhao R., Yang Y., Meng S., Wang C., Liu Z. Nano Research 2012, 5, 543-549.

51. Lafferentz L., Eberhardt V., Dri C., Africh C., Comelli G., Esch F., Hecht S., Grill L. Nature Chem. 2012, 4, 215-220.

52. Song C., Ye R., Bo-Zhong Acta Chimica Sinica-Chinese Editio 2009, 67, 2038-2042.

53. Zhang X., Wang Y., Chen P., Rong Y., Liu M. Phys. Chem. Chem. Phys. 2016, 18, 14023-14029.

54. Crane J.M., Hal S.B. Biophys. J. 2001, 80, 1863-1872.

55. Paolesse R., Nardis S., Sagone F., Khoury R.G. J. Org. Chem. 2001, 66, 550-556.

56. Koszarna B., Gryko D.T J. Org. Chem. 2006, 71, 3707-3717.

57. Maiorova L.A., Koifman O.I., Burmistrov V.A., Kuvshinova S.A., Mamontov A.O. Prot. Met. Phys. Chem. Surf. 2015, 51(1), 85-92.

58. Petrova M.V., Maiorova L.A., Gromova O.A., Bulkina T.A., Ageeva T.A., Koifman O.I. Macroheterocycles 2014, 7, 267-271.

59. Vu T.T. Metalporphyrinoids: Stability in Solution and Solid Phase, Features, Electrocatalysis and Thin-Film Materials on their Basis. PhD thesis, Ivanovo, Russia, 2016. 222 p. (in Russ).

Received 12.12.2017

Accepted 07.06.2018 